\title{
Degradation of Bioplastics in Soil and Their Degradation Effects on Environmental Microorganisms
}

\author{
Dinesh Adhikari, Masaki Mukai, Kenzo Kubota, Takamitsu Kai, Nobuyuki Kaneko, \\ Kiwako S. Araki, Motoki Kubo \\ Department of Biotechnology, Faculty of Life Sciences, Biwako-Kusatsu Campus, Ritsumeikan University, \\ Kusatsu, Shiga, Japan \\ Email:kubo@sk.ritsumei.ac.jp
}

Received 10 December 2015; accepted 26 February 2016; published 29 February 2016

Copyright (C) 2016 by authors and Scientific Research Publishing Inc.

This work is licensed under the Creative Commons Attribution International License (CC BY). http://creativecommons.org/licenses/by/4.0/

(c) (i) Open Access

\begin{abstract}
Degradation of three kinds of bioplastics and their effects on microbial biomass and microbial diversity in soil environment were analyzed. The degradation rate of bioplastic in soil was closely related to the main components in the bioplastics. Poly (butylene succinate)-starch (PBS-starch) and poly (butylene succinate) (PBS) were degraded by $1 \%$ to $7 \%$ after 28 days in a soil with an initial bacterial biomass of $1.4 \times 1^{9}$ cells/g-soil, however poly lactic acid (PLA) was not degraded in the soil after 28 days. When the powdered-bioplastics were examined for the degradation in the soil, PBS-starch also showed the highest degradability ( $24.4 \%$ degradation after 28 days), and the similar results were obtained in the case of long-term degradation experiment ( 2 years). To investigate the effect of bacterial biomass in soil on biodegradability of bioplastics, PBS-starch was buried in three kinds of soils differing in bacterial biomass $\left(7.5 \times \mathbf{1 0}^{6}, 7.5 \times 10^{7}\right.$, and $7.5 \times 10^{8} \mathrm{cells} / \mathrm{g}$ soil). The rate of bioplastic degradation was enhanced accompanied with an increase of the bacterial biomass in soil. 16S rDNA PCR-DGGE analysis indicated that the bacterial diversity in the soil was not affected by the degradation of bioplastics. Moreover, the degradation of bioplastic did not affect the nitrogen circulation activity in the soil.
\end{abstract}

Keywords

Bioplastics, Biodegradation, Soil Microorganisms, Bacterial Diversity

\section{Introduction}

Non-biodegradable petrochemical plastics such as polypropylene and polyethylene are used in several fields.

How to cite this paper: Adhikari, D., Mukai, M., Kubota, K., Kai, T., Kaneko, N., Araki, K.S. and Kubo, M. (2016) Degradation of Bioplastics in Soil and Their Degradation Effects on Environmental Microorganisms. Journal of Agricultural Chemistry and Environment, 5, 23-34. http://dx.doi.org/10.4236/jacen.2016.51003 
The waste plastics are disposed by incineration and/or landfill treatments. This has caused environmental problems such as air, soil and water pollutions [1] [2]. Recently, many kinds of bioplastics, such as poly (hydroxylalkanoate) (PHA), poly (lactic acid) (PLA), poly (butylene succinate) (PBS) and PBS-co-adipate (PBSA), which contain natural materials or biodegradable polymers, have been developed. The use of these bioplastics as a replacement for conventional plastics is being tried in agricultural fields, medical fields, and the dairy industries [3]-[5].

In agricultural fields, waste bioplastics are supposed to be disposed in the soil after use. The degradation of the bioplastics by soil microorganisms has been reported [6]-[9], and several microorganisms, such as Bacillus sp. and Aspergillus sp., are isolated and identified as bioplastic degraders from the soil environment. Their degradation ability and mechanism of bioplastics degradation (such as PBS, PBSA, and PLA) have also been investigated [10]-[12], and the bioplastic-degrading enzymes are characterized [13]. However, the relationship between the degradation of bioplastics and the bacterial biomass in the soil are not clearly investigated. Studies about the ecotoxicity of bioplastic degradation in the soil environment are at the beginning stage.

Soil microorganisms are sensitive to the environmental changes due to pollution. Therefore, the evaluation of the soil microorganisms can be an indicator of the environmental condition [14] [15]. Generally, over $1 \times 10^{8}$ bacterial cells are present in one-gram soil. However, high levels of contamination by petroleum hydrocarbons or heavy metals lead to a decrease in the bacterial biomass in the soil [16] [17]. Moreover, several soil pollutants influence the microbial diversity [18] [19]. In agricultural soils, $\mathrm{N}$ and P circulation activities are closely related to the soil microbial biomass [20]-[22]. Especially in agricultural soils, analysis of $\mathrm{N}$ circulation activity can be an important indicator to detect the soil pollution. Therefore, the effect of bioplastic degradation on the soil environment can be evaluated by analyzing microbial biomass and diversity. In this paper, the degradation of bioplastics in the soil over a short- and long-terms and the effects on microorganisms (biomass and diversity) and material circulation (nitrogen circulation activity) in soil are investigated.

\section{Materials and Methods}

\subsection{Plastic Materials}

Three commercial bioplastics and a non-biodegradable petrochemical plastic were used for this study. These plastics are commonly used to bind vegetables or fruits in agricultural fields. The commercial PBS (Showa Highpolymer, Tokyo, Japan), PBS-starch (Matsubara Shoji, Tokyo, Japan), and PLA (Mitsui Chemicals, Tokyo, Japan) were the bioplastics, while PA66 was the non-biodegradable petrochemical plastic used in this study. The thickness of each plastic was $2 \mathrm{~mm}$. For a separate experiment, all of the three kinds of bioplastics (PBS, PBSstarch, and PLA) were powdered by using a Power Grinder (T-351, Rong Tsong Precision Technology, Taichung, Taiwan). Physical properties of the bioplastics are shown in Table 1. PBS-starch film is a blend of PBS (50\%) and starch (50\%).

\subsection{Short-Term Degradation of Bioplastics and Non-Biodegradable Plastic Films (28 Days)}

Each of the non-sterilized bioplastics (PBS, PBS-starch, and PLA) and non-biodegradable petrochemical plastic (PA66) films $(3 \mathrm{~cm} \times 3 \mathrm{~cm})$ were buried $(5 \%(\mathrm{w} / \mathrm{w}))$ in an agricultural soil $(100 \mathrm{~g}$-soil/pot, bacterial biomass $7.5 \times$ $10^{8}$ cells/g-soil). The pots were kept under controlled condition $\left(25^{\circ} \mathrm{C}\right.$ and $60 \%$ relative humidity) for 28 days. Moisture content of the soils was maintained around $35 \%$ to $40 \%$ throughout the experiment. The plastics films

Table 1. Physical properties of bioplastics used in this study ${ }^{a}$.

\begin{tabular}{ccc}
\hline Property & PLA & PBS \\
\hline Tensile strength (MPa) & 39 & 20 \\
Tensile elongation (\%) & 220 & 320 \\
Flexural strength (MPa) & 64 & 37 \\
Flexural modulus (MPa) & 2400 & 686 \\
Izod impact strength (J/m) & 65 & 59 \\
\hline
\end{tabular}

\footnotetext{
${ }^{\mathrm{a}}$ Properties of PBS-starch was not determined.
} 
were recovered from the soil every 7 days, and the residual weights were measured after washing using an ultrasonic washer. The degradation ratio was calculated by the weight loss of the plastics. In addition, the surface of each plastic was observed by a digital stereo microscope (VHX-1000, Keyence, Osaka, Japan) and scanning electron microscope (SEM, VE-8800, Keyence, Osaka, Japan) after sputtering of Pt-Pd.

\subsection{Short-Term Degradation of Powdered-Bioplastics (28 Days)}

PBS, PBS-starch, and PLA were powdered by using a Power Grinder until ca. $250 \mu \mathrm{m}$ of diameter (T-351, Rong Tsong Precision Technology, Taichung, Taiwan). The surface area of the powdered-bioplastic was about 12 times larger than that of commercial bioplastic (the surface area of the plastics was estimated using a digital stereo microscope (VHX-1000, Keyence, Osaka, Japan). The powdered-bioplastics were buried (0.25\% (w/w)) in the same agricultural soil (50 g soil/pot) used for burying the plastic films. The pots were kept under controlled condition ( $25^{\circ} \mathrm{C}$ and $60 \%$ relative humidity) for 28 days. Moisture content of the soils was maintained around $35 \%$ to $40 \%$ throughout the experiment. The soil samples were recovered from the pots every 7 days, and the degradation of powdered-bioplastics was analyzed based on the decrease of the total carbon (TC) in the soil. TC in the soil was analyzed by using TOC-V $\mathrm{V}_{\mathrm{CPH}}$ equipped with a solid sample combustion unit of SSM-5000A (Shimadzu, Kyoto, Japan).

\subsection{Effect of Bacterial Biomass on Degradation of Bioplastic Films in Soil}

To investigate the effect of the bacterial biomass on the bioplastic degradation in the soil, PBS-starch film (3 cm $\times$ $3 \mathrm{~cm}$ ) was buried in soils varying in bacterial biomass $\left(7.5 \times 10^{6}, 7.5 \times 10^{7}\right.$, and $7.5 \times 10^{8}$ cells/g-soil). The initial bacterial biomass in the original soil was $7.5 \times 10^{8}$ cells/g. Other two levels of bacterial biomass was adjusted by mixing sterilized soil in the original soil. The sterilized soil was prepared by autoclaving $\left(121^{\circ} \mathrm{C}, 2 \mathrm{~atm}\right.$ for $60 \mathrm{~min}$ ).

In another experiment, three different soils were collected from a riverside, a mountain, and an agricultural farm around the city of Kusatsu (Shiga prefecture, Japan). Each soil was filled into pots (approximately three kg-soil/pot), and three sheets of PBS-starch film $(3 \mathrm{~cm} \times 3 \mathrm{~cm})$ were buried in each pot.

In both experiments, the weight loss of the PBS-starch film was measured after 7 days of incubation at room temperature $\left(25^{\circ} \mathrm{C}\right)$, and the degradation ratio was calculated from the weight loss.

\subsection{Long-Term Degradation of Bioplastics and Non-Biodegradable Plastic (2 Years)}

Three bioplastics (PBS, PBS-starch, and PLA) and a non-biodegradable petrochemical plastic (PA66) were buried in an agricultural field (field size was $1 \mathrm{~m} \times 1 \mathrm{~m}$ ). The plastics were recovered from the soil after 2 years, and the surface of each plastic was observed as described above by using a digital stereo microscope (VHX1000, Keyence, Osaka, Japan) and SEM (VE-8800, Keyence, Osaka, Japan).

\subsection{Quantification of Bacterial and Fungal Biomass in Soil}

For quantification of bacterial and fungal biomass, the soil adjacent to the plastics was sampled. The bacterial biomass in the soil was quantified by the environmental DNA (eDNA) extracted by slow stirring analysis method [16]. The fungal biomass in the soil was quantified by the plate-counting method [23]. For plate-counting, a soil suspension was spread onto PDA-AB-RB agar medium (200 g potato, 15 g glucose, 30 mg rose bengal, 50 mg chloramphenicol, $1 \mathrm{mg}$ carbenicillin, $100 \mathrm{mg}$ streptomycin, $10 \mathrm{mg}$ tetracycline and 20g agar, per liter), and the agar plate was incubated at $30^{\circ} \mathrm{C}$. The fungal colony forming units (CFU/g-soil) were counted after 4 days of incubation.

\subsection{Analysis of Bacterial Diversity by $16 \mathrm{~S}$ rRNA Gene PCR-DGGE}

The variable V3 region of bacterial 16S rRNA gene (corresponding to positions 341 to 926 in the Escherichia coli) was analyzed by denaturing gradient gel electrophoresis (DGGE). The eDNA was extracted from the soil samples by the slow-stirring method [16]. The extracted eDNA was purified by using GEL-M (Viogene, Taipei, Taiwan) and amplified by PCR (PC708, Astec, Fukuoka, Japan) with primers DGGE-F (5’-CGCCC GCCGC GCCCC GCGCC CGTCC CGCCG CCCCC GCCCG CCTAC GGGAG GCAGC AG-3’) and DGGE-R (5’- 
CCGTC AATTC CTTTG AGTTT-3’) [24] [25]. The PCR reaction included an initial denaturation step at $94^{\circ} \mathrm{C}$ for $5 \mathrm{~min}, 30$ cycles of a denaturation step at $94^{\circ} \mathrm{C}$ for $30 \mathrm{sec}$, a primer annealing step at $60^{\circ} \mathrm{C}$ for $30 \mathrm{sec}$, and an extension step at $72^{\circ} \mathrm{C}$ for $1 \mathrm{~min}$, followed by a final elongation step of $72^{\circ} \mathrm{C}$ for $5 \mathrm{~min}$. The denaturant concentration in $6 \%(\mathrm{w} / \mathrm{v})$ polyacrylamide gel was from $20 \%$ to $60 \%$, and electrophoresis was performed with the D-Code system (Bio-Rad Laboratories, CA, USA) for 10 hours at $60^{\circ} \mathrm{C}, 80 \mathrm{~V}$. After electrophoresis, the gel was stained by SYBR Gold (Invitrogen, CA, USA) and analyzed by Kodak 1D Image Analysis Software (Kodak, NY, USA). Cluster analysis (single linkage) was carried out by using the software FP Quest (Bio-Rad Laboratories, CA, USA).

\subsection{Analysis of the Nitrogen Circulation Activity in Soil}

To investigate the effect of bioplastics degradation on microbial activities, the nitrogen circulation activity was determined as described previously [20] [22]. Bacterial biomass, ammonium oxidation activity, and nitrite oxidation activity were used to analyze the nitrogen circulation activity. The bacterial biomass was estimated by eDNA analysis method [16] as mentioned above. To estimate the ammonium and nitrite oxidation activities, 2-g soil (moisture was adjusted to $60 \%$ water holding capacity) was taken into a $50 \mathrm{ml}$ plastic tube, then $60 \mu \mathrm{mol}$ of $\mathrm{NH}_{4}^{+}-\mathrm{N}\left(\left(\mathrm{NH}_{4}\right)_{2} \mathrm{SO}_{4}\right)$ or $\mathrm{NO}_{2}^{-}-\mathrm{N}\left(\mathrm{KNO}_{2}\right)$ was added. After 3 days of incubation at $25^{\circ} \mathrm{C}$, decrease rates of $\mathrm{NH}_{4}^{+}-\mathrm{N}$ and $\mathrm{NO}_{2}^{-}-\mathrm{N}$ were measured. Each of the three properties (bacterial biomass, ammonium oxidation activity, and nitrite oxidation activity) was scored 0 - 100 points. Bacterial biomass of $6 \times 10^{8}$ cells/g-soil was defined as 100 points. Similarly, complete reduction of added $\mathrm{NH}_{4}{ }^{+}$or $\mathrm{NO}_{2}{ }^{-}$during the incubation was defined as 100 points for ammonium or nitrite oxidation activities, respectively. Based on these 3 scores, a radar chart was constructed, and then the nitrogen circulation activity was calculated.

\section{Results}

\subsection{Short-Term Degradation of Commercial Bioplastics and Non-Biodegradable Plastic in Soil (28 Days)}

Bioplastics are degraded by many kinds of microorganisms in nature, and the bioplastics are converted into water and carbon dioxide by microbial metabolism. Non-biodegradable petrochemical plastics such as PA66, polypropylene and polyethylene remain in the environment for a long time because the plastics are resistant to invade by microorganisms. To analyze the biodegradability of each plastic in nature, 3 kinds of commercial bioplastics (PBS, PBS-starch and PLA) and a non-biodegradable petrochemical plastic (PA66) were buried in an agricultural soil (initial bacterial biomass: $1 \times 10^{9}$ cells/g-soil), and the weight reductions of plastics were analyzed after 28 days. The weight reductions of PBS-starch and PBS were $7.2 \%$ and $1.2 \%$, respectively, however PLA and PA66 remained undegraded (Figure 1). This result indicates that the degradation of bioplastics

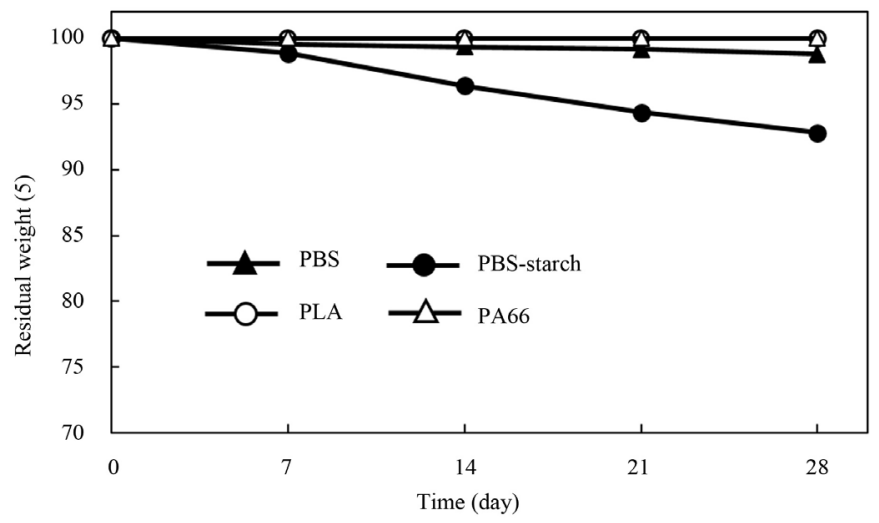

Figure 1. Degradation of PBS-starch, PBS, PLA, and PA66 in the short-term experiment (28 days). Closed triangles: PBS, closed circles: PBS-starch, opened circles: PLA, opened triangles: PA66. The degradation ratios were calculated by the weight reduction. Each experiment was carried out in duplicate. 
in nature is closely related to the chemical component and bonding characteristics of the plastic.

To determine the influences of the degradation products from the bioplastics on the soil environment, time courses of microbial biomass in the soil were analyzed. The bacterial and fungal biomass in the soil samples did not change so much over the 28 days (Figure 2(a) and Figure 2(b)). These results suggest that the degradation products from PBS and PBS-starch do not affect the microbial biomass and diversity.

\subsection{Short-Term Degradation Experiment of Powdered-Bioplastics (28 Days)}

To analyze the biodegradability of each bioplastic clearly, the powdered bioplastics were added in soil and the rate of decrease in soil TC was measured after 28 days. The degradation ratios of PBS-starch, PBS, and PLA after 28 days were $24.4 \%, 16.8 \%$, and $13.8 \%$, respectively. These bioplastics were degraded faster than the commercial bioplastics (Figure 3). The enhancement of biodegradability of powdered bioplastics in the soil seemed to be caused by increase in the surface area. The tendency of the relative biodegradabilities of each powderedbioplastics was similar to those of the commercial bioplastics.

\subsection{Effect of Bacterial Biomass on Degradation of Bioplastics in Soil}

In order to analyze the effect of bacterial biomass on the degradation of bioplastics in the soil, PBS-starch films were buried in 3 kinds of soils containing the same bacterial diversity but different levels of bacteria biomass (A: $7.5 \times 10^{6}$, B: $7.5 \times 10^{7}$ and C: $7.5 \times 10^{8}$ cells/g-soil), and the reduction in the weight of bioplastic was measured. The soil samples were prepared by mixing different ratios of sterilized and non-sterilized soils (see Materials and Methods section). The degradation ratio was greater when the bacterial biomass was higher (Figure 4). This

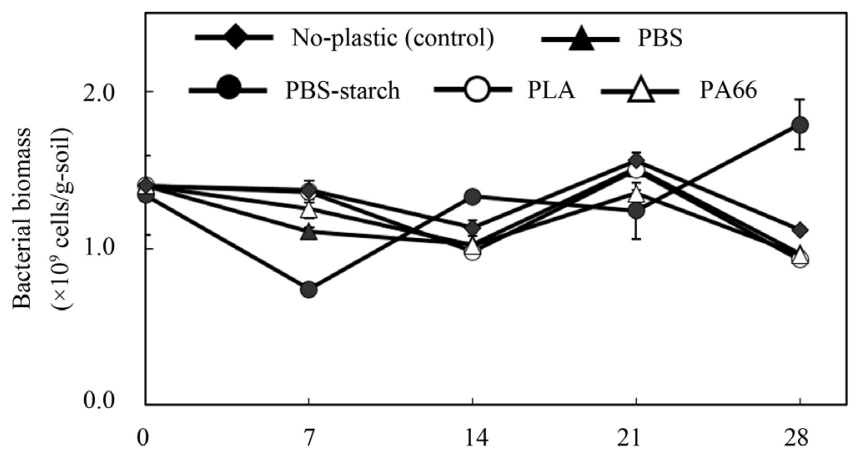

(a)

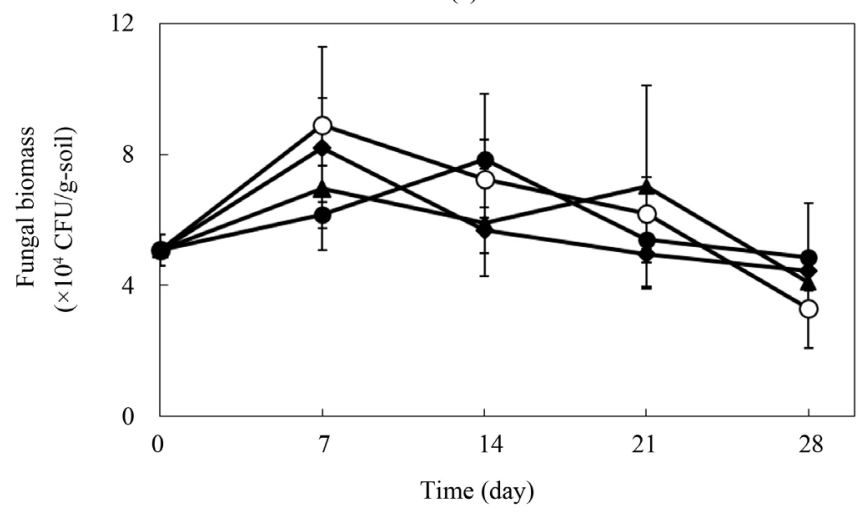

(b)

Figure 2. Time course of bacterial biomass (a) and fungal biomass (b) in the short-term experiment (28 days). Closed diamonds: no plastic (control), closed triangles: PBS, closed circles: PBS-starch, opened circles: PLA. The bacterial biomass and the fungal biomass were quantified by the eDNA analysis method and plate counting method, respectively. Each experiment was carried out in duplicate. 


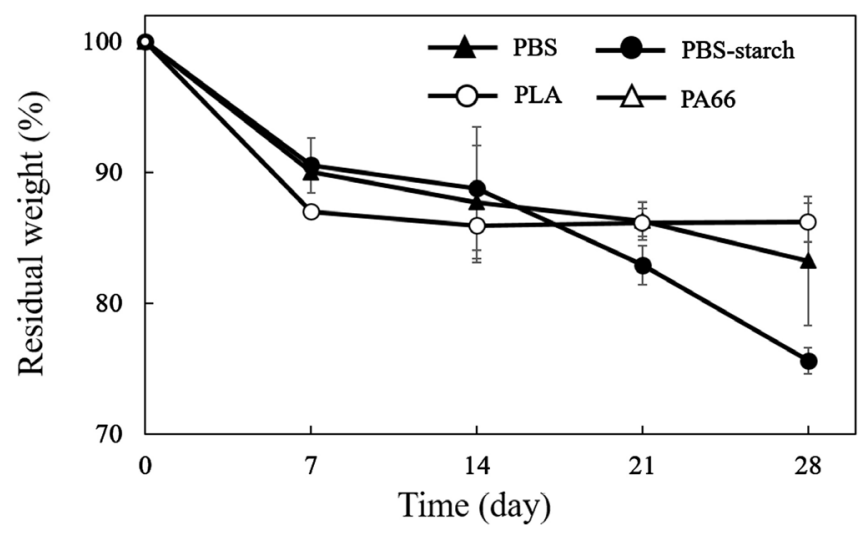

Figure 3. Degradation ratios of powdered-bioplastics in the shortterm experiment (28 days). Closed triangles: PBS, closed circles: PBS-starch, opened circles: PLA The degradation ratios were calculated by analyzing reduction of soil TC. Each experiment was carried out in duplicate.

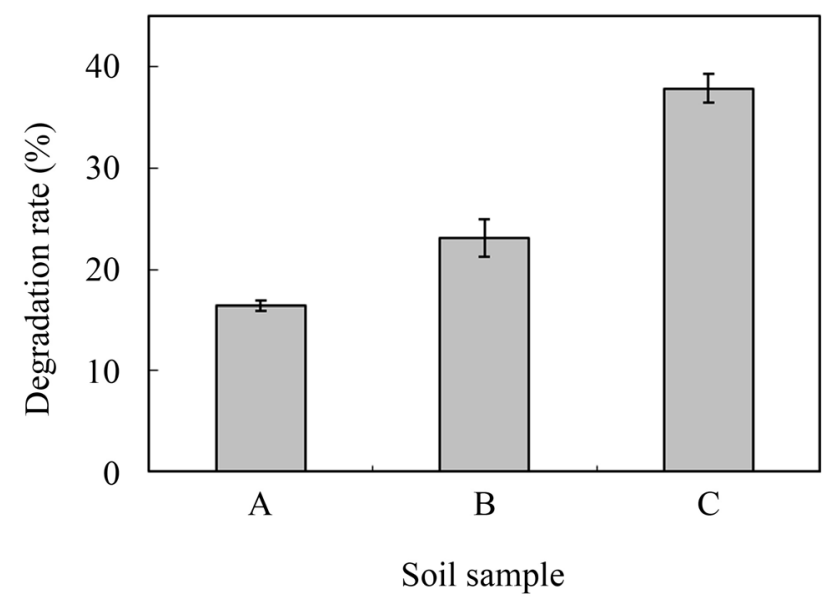

Figure 4. Relationship between bacterial biomass and degradation of bioplastic film (PBS-starch). Bacterial biomass in soils were A: $7.5 \times 10^{6}$, B: $7.5 \times 10^{7}$, C: $7.5 \times 10^{8}$ cells/g-soil. The degradation ratios were calculated by the weight reduction. Each experiment was carried out in duplicate.

result suggests that the degradation of bioplastic depends on the bacterial biomass in the soil.

In the next step, PBS-starch films were buried in 3 kinds of environmental soil samples differing in bacterial biomass and diversity. The degradation ratios of PBS-starch in the soils from a mountain (5.8 $\times 10^{7} \mathrm{cells} / \mathrm{g}$-soil), from a riverside $\left(1.0 \times 10^{8}\right.$ cells/g-soil), and from an agricultural farm $\left(7.8 \times 10^{8}\right.$ cells/g-soil $)$ were $8.0 \%, 23.4 \%$, and $28.3 \%$, respectively (Table 2). These results also indicate that PBS-starch degradation in the environmental soil samples is closely related to the bacterial biomass.

\subsection{Long-Term Degradation of Bioplastics in Soil (2 Years)}

Three kinds of commercial bioplastics (PBS, PBS-starch and PLA) and a non-biodegradable petrochemical plastic (PA66) were buried in an agricultural field (initial bacterial biomass: $5.4 \times 10^{8}$ cells/g-soil) for 2 years. The degradation of each plastic and the effect of the degradation on the soil bacterial biomass and diversity were analyzed. The surfaces of all bioplastics turned dark, however that of PA66 did not change. Of the bioplastics, the structures of PBS and PBS-starch were considerably more degraded than that of PLA. This result indicates that the degradation rate of PBS and PBS-starch in the environment is faster than that of PLA. This result was 
similar to that from the short-term (28 days) degradation experiment. The bacterial biomass in PBS, PBS-starch, and PLA buried soils did not differ significantly to that in the control experiment (5.4 $\times 10^{8}$ cells/g-soil), however the bacterial biomass in the soil with PA66 decreased slightly $\left(4.2 \times 10^{8}\right.$ cells/g-soil) (Figure 5).

PCR-DGGE analysis was carried out to investigate the bacterial diversity in each soil sample (Figure 6). The band patterns were divided into 3 clusters. The patterns from PBS and PA66 belonged to the same cluster, and those from PLA and PBS-starch belonged to the same cluster. The BSI (band similarity index) among the clusters was above $80 \%$, therefore the degradation of bioplastics and PA66 in the soil for 2 years did not seem to

Table 2. Bacterial biomass degradation ratio of bioplastics in different soils.

\begin{tabular}{ccc} 
Soil & Bacterial biomass (cells/g-soil) & Degradation ratio of PBS-starch after 7 days (\%) \\
\hline Mountain & $5.8 \times 107$ & 8.0 \\
Riverside & $1.0 \times 108$ & 23.4 \\
Agricultural field & $7.8 \times 108$ & 28.3 \\
\hline
\end{tabular}

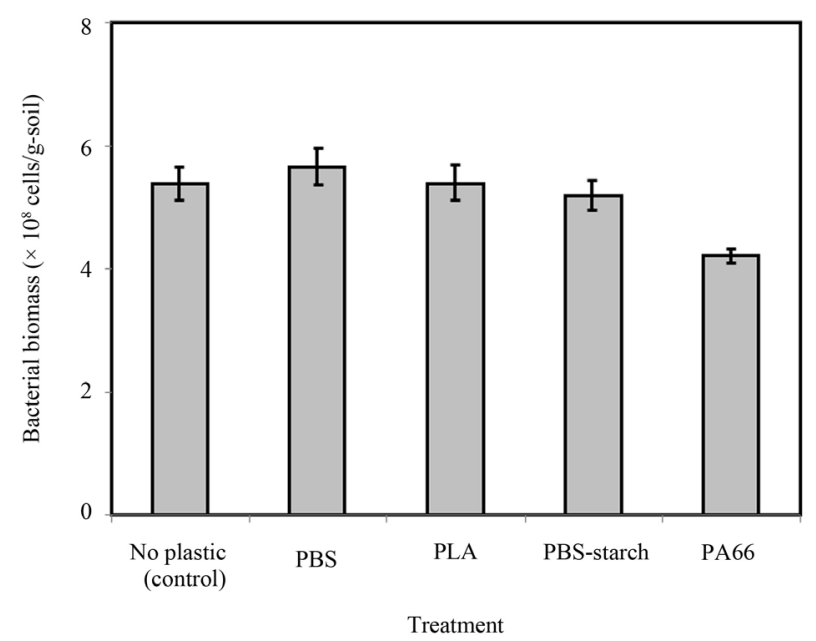

Figure 5. Bacterial biomass in soil after 2 year experiment. The bacterial biomass was quantified by the eDNA analysis method.
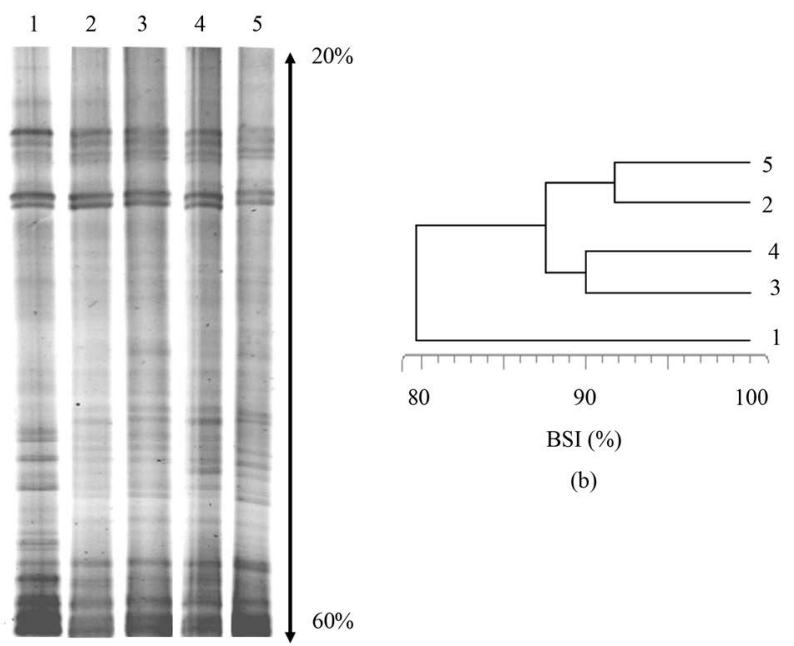

(b)

(a)

Figure 6. 16s rRNA gene PCR-DGGE analysis of bacterial diversity in the long-term experiment (2 years). A: band pattern, B: similarity analysis. 1: no plastics, 2: PBS, 3: PLA, 4: PBS-starch, 5: PA66. Similarity index was calculated by cluster analysis (single linkage) using the software FP Quest. 
influence the bacterial diversity. These results indicate that the soil bacterial biomass and diversity were not influenced by the degradation of bioplastics.

\subsection{Observation of the Bioplastic Surface by SEM}

The plastic samples which was buried in soil for 28 days and 2 years were observed by SEM, and changes in the plastic surfaces were analyzed (Figure 7). The surfaces of PBS and PBS-starch were drastically changed in both short- and long-term experiments, confirming the decay of these bioplastics. In the case of PLA, the surface structure changed slightly after 28 days, and the structure was further decayed after 2 years. On the other hand, PA66 did not change after 28 days or 2 years of degradation, thus the non-biodegradable petrochemical plastic seemed to be very recalcitrant to biodegradation in the soil environment. These results indicate that the structures of the bioplastics were degraded and decayed in the soil environment, though the degradation rates differed among the bioplastics. PBS and PBS-starch were easily degraded, but PLA needed a long time for a significant degradation.

\subsection{Effect of Bioplastic-Degradation on the Nitrogen Circulation Activity in Soil}

Biodegradation of PLA, PBS, and PBS-starch in the agricultural soil did not significantly affect the bacterial biomass, however the bacterial diversity was slightly changed. In order to investigate the influences on the microbial activity in agricultural soils by the degradation of bioplastics, the nitrogen circulation activities in the soils buried with PBS, PBS-starch, or PLA were analyzed. The activity of the nitrogen circulation in the soil was measured based on the bacterial biomass, $\mathrm{NH}_{4}^{+}$oxidation activity, and $\mathrm{NO}_{2}^{-}$oxidation activity.

After 84 days of incorporation of bioplastics in soil, the oxidation activities of $\mathrm{NH}_{4}^{+}$and $\mathrm{NO}_{2}^{-}$and the bacterial biomass were decreased in the soils with PLA. Especially, the $\mathrm{NO}_{2}^{-}$oxidation activity was significantly changed, which was $26 \%$ lower than that without bioplastic (control experiment). The nitrogen circulation activity (21.5 points) was almost half the level of the control experiment (40.0 points) (Figure 8(a)).

On the other hand, the nitrogen circulation activity in soil with PBS was almost the same level as the control experiment after 84 days of treatment (Figure 8(b)). The activities were 21.1 points in PBS-buried soil and 24.2 points in control experiment. The bacterial biomass and the oxidation activities of $\mathrm{NH}_{4}^{+}$and $\mathrm{NO}_{2}^{-}$in PBSstarch buried soil were not influenced by the degradation process (Figure 8(c)).

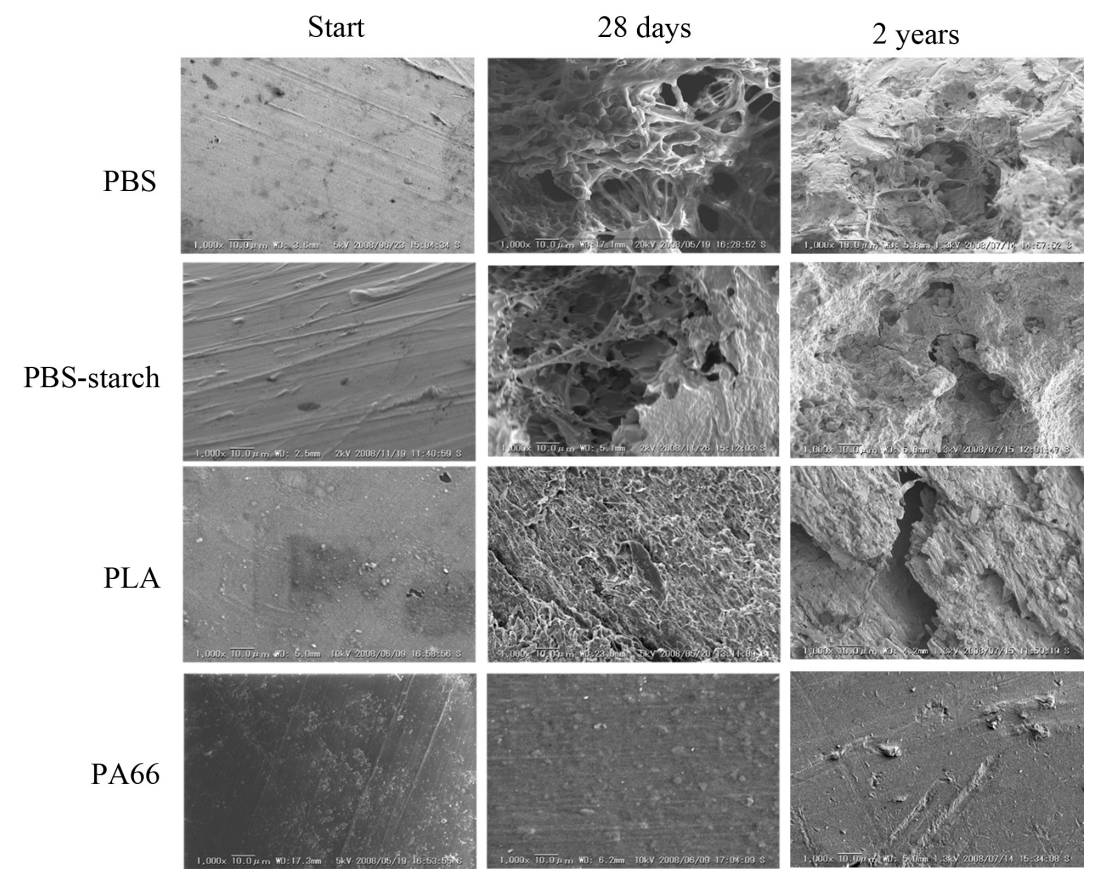

Figure 7. SEM analysis of surface of PBS-starch, PBS, PLA, and PA66. Each sample was observed after sputtering of Pt-Pd. 


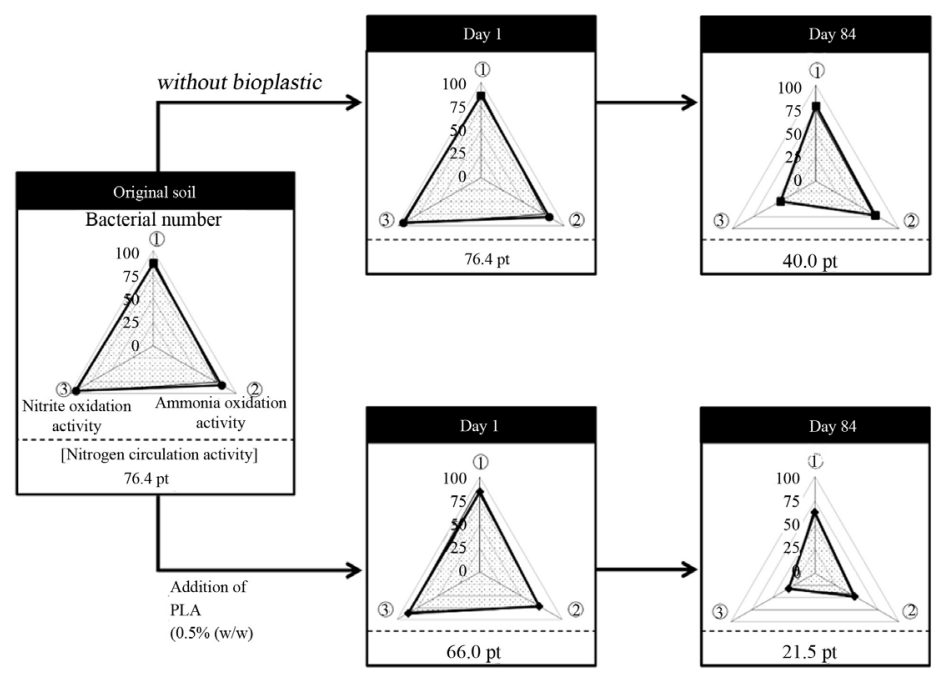

(a)
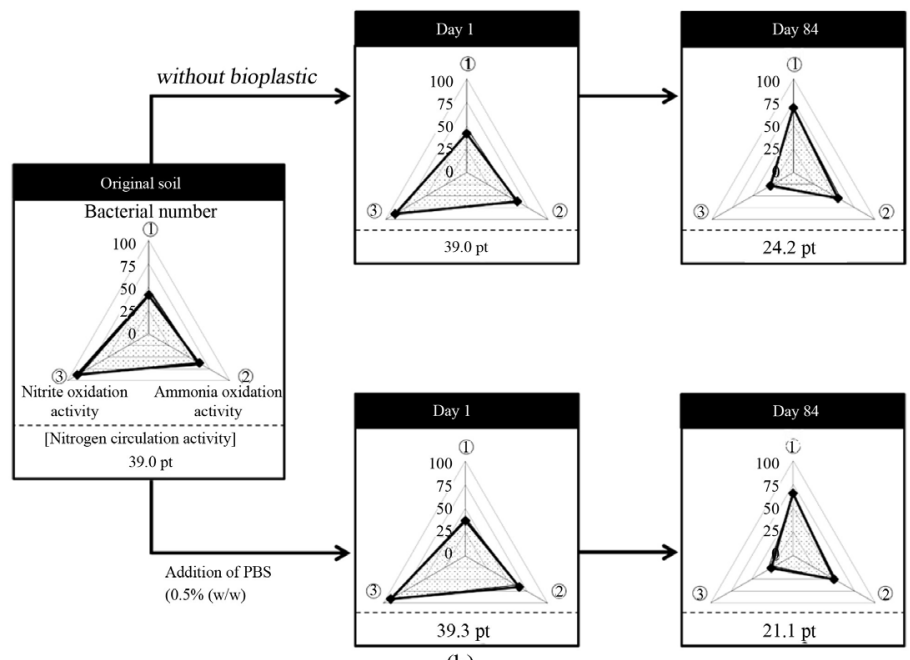

(b)

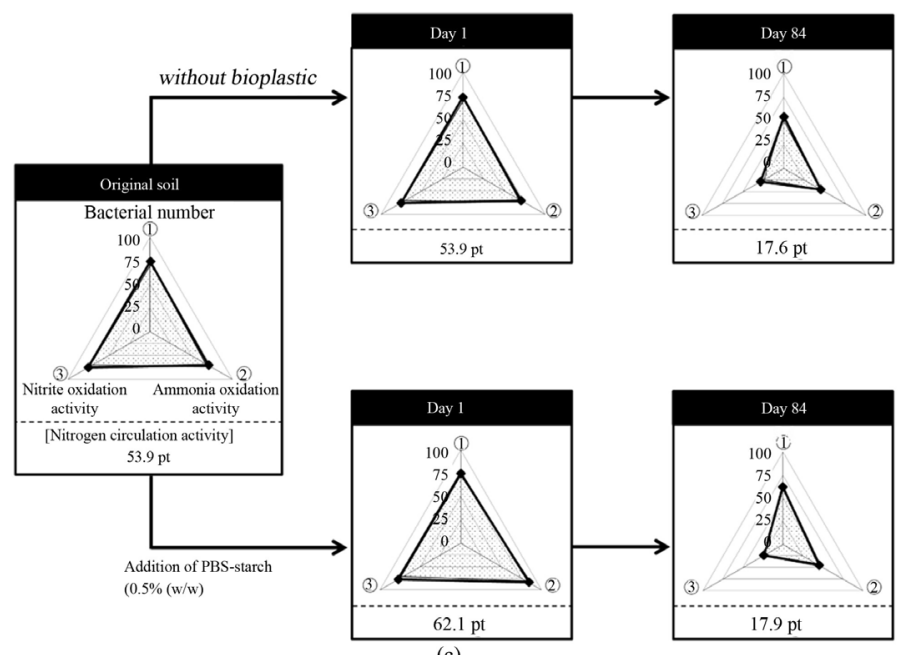

Figure 8. Nitrogen circulation activities in soils before and after 84 days of PBS-starch, PBS, and PLA burying. (a): PBSstarch, (b): PBS, (c): PLA. Nitrogen circulation activity was evaluated based on the bacterial biomass, ammonia-oxidizing activity, and nitrite-oxidizing activity using a radar chart following the methods of Adhikari et al. (2014) [22]. 
These results indicate that the degradation of PBS and PBS-starch did not affect on the nitrogen circulation activity, but that of PLA seemed to show a negative effect for the activities of both ammonium and nitrite-oxidizing bacteria.

\section{Discussion}

The degradabilities of the bioplastics in soil environment differed considerably, depending on the main polymer component. The degradation speed of PBS-starch was faster than those of PLA and PBS after 28 days. Especially, powdered-PBS-starch (which is a blend of PBS and starch) was degraded by $24 \%$. Previous studies have also reported that both PBS and PBS-starch are degraded and utilized by soil microorganisms [9] [26].

On the other hand, some kinds of bioplastics such as PLA persisted in soils for a long time. Reducing the size and increasing the surface area by powdering enhanced the degradation speed of some bioplastics in this study; however powdered-PLA was difficult to be degraded in the soil. Degradation of PLA required both structural change and microbial attack [27]. Therefore, for PLA degradation, microbial attack at a high temperature (such as by thermophilic bacteria under a composting process) might be needed. For the treatment of waste bioplastics in the soil, the biodegradability of each bioplastic should be considered.

The degradation rates of bioplastics were proportionate to the bacterial biomass in the soil. Many kinds of bioplastic-degrading bacteria might exist in the soil environments, and higher number of bioplastic-degrading bacteria seemed to be existed in the soil rich in total bacterial biomass. Since, a fertile soil was rich in bacterial biomass; bioplastics seemed to be efficiently degraded in fertile soil environments.

When bioplastics were buried in soils for 28 days and 2 years, bacterial biomass and diversity were not influenced by the degradation of bioplastics. In the case of using powdered-bioplastics, the bacterial biomass did not change either (data not shown). However, the bacterial biomass decreased when PA66 was buried in soil for 2 years. The presence of PA66 in the soil might lead to the inhibition of aeration for the well-functioning of microorganisms.

Utilization of bioplastics in agricultural fields was expected to increase in the future, thus the influence of bioplastic degradation on material circulation in the agricultural soil should be understood. Nitrogen was an essential nutrient for plant growth; therefore, nitrogen circulation was one of the most important activities for both conventional and organic agriculture. In this study, nitrogen circulation activity in bioplastic buried soil was measured, and a negative effect of PLA degradation on the activity was observed. In addition, the fungal biomass was not increased by the degradation of bioplastics in this experiment; however studies on the effects of large amounts of buried bioplastics in agricultural fields on the growth of phytopathogens would be necessary for the safe useage of bioplastics [28].

Although the degradation of bioplastics in this study did not affect the bacterial diversity in the soil environment, the degradation rate in the soil was low. New bioplastics having high degradation rates in soil and safe for the environmental microorganisms should be developed in the near future.

\section{References}

[1] Shimano, M. (2001) Biodegradation of Plastics. Current Opinion in Biotechnology, 12, 242-247. http://dx.doi.org/10.1016/S0958-1669(00)00206-8

[2] Shah, A.A., Hasan, F., Hameed, A. and Ahmed, S. (2008) Biological Degradation of Plastics: A Comprehensive Review. Biotechnology Advances, 26, 246-265. http://dx.doi.org/10.1016/j.biotechadv.2007.12.005

[3] Lunt, J. (1998) Large-Scale Production, Properties and Commercial Applications of Polylactic Acid Polymers. Polymers Degradation Stability, 59, 145-152. http://dx.doi.org/10.1016/S0141-3910(97)00148-1

[4] Gross, R.A. and Kalra, B. (2002) Biodegradable Polymers for the Environment. Science, 297, 803-807. http://dx.doi.org/10.1126/science.297.5582.803

[5] Bonanomi, G., Chiurazzi, M., Caporaso, S., Del Sorbo, G., Moschetti, G. and Felice, S. (2008) Soil Solarization with Biodegradable Materials and Its Impact on Soil Microbial Communities. Soil Biology and Microbiology, 40, 19891998. http://dx.doi.org/10.1016/j.soilbio.2008.02.009

[6] Suyama, T., Tokiwa, Y., Ouichanpagdee, P., Kanagawa, T. and Kamagata, Y. (1998) Phylogenetic Affiliation of Soil Bacteria That Degrade Aliphatic Polyesters Available Commercially as Biodegradable Plastic. Applied and Environmental Microbiology, 64, 5008-5011.

[7] Nakamura, K., Tomita, T., Abe, N. and Kamio, Y. (2001) Purification and Characterization of an Extracellular 
Poly(L-Lactic Acid) Depolymerase from a Soil Isolate, Amycolatopsis sp. Strain K104-1. Applied Environmental Microbiology, 67, 345-353. http://dx.doi.org/10.1128/aem.67.1.345-353.2001

[8] Kim, D.Y. and Rhee, Y.H. (2003) Biodegradation of Microbial and Synthetic Polyesters by Fungi. Applied Microbiology and Biotechonology, 61, 300-308. http://dx.doi.org/10.1007/s00253-002-1205-3

[9] Teeraphatpornchai, T., Nakajima-Kambe, T., Shigeno-Akutsu, Y., Nakayama, M., Nomura, N., Nakahara, T. and Uchiyama, H. (2003) Isolation and Characterization of a Bacterium That Degrades Various Polyester-Based Biodegradable Plastics. Biotechnology Letters, 25, 23-28. http://dx.doi.org/10.1023/A:1021713711160

[10] Kim, M.N., Kim, W.G., Weon, H.Y. and Lee, S.H. (2008) Poly(L-Lactide)-Degrading Activity of a Newly Isolated Bacterium. Journal of Applied Polymer Science, 109, 234-239. http://dx.doi.org/10.1002/app.26658

[11] Ishii, N., Inoue, Y., Tagaya, T., Mitomo, H., Nagai, D. and Kasuya, K. (2008) Isolation and Characterization of Poly (butylene succinate)-Degrading Fungi. Polymers Degradation Stability, 93, 883-888. http://dx.doi.org/10.1016/j.polymdegradstab.2008.02.005

[12] Kamiya, M., Asakawa, S. and Kimura, M. (2007) Molecular Analysis of Fungal Communities of Biodegradable Plastics in Two Japanese Soils. Soil Science and Plant Nutrition, 53, 568-574. http://dx.doi.org/10.1111/j.1747-0765.2007.00169.x

[13] Lee, S.H. and Kim, M.N. (2010) Isolation of Bacteria Degrading Poly(butylenes succinate-co-butylene adipate) and Their Lip A Gene. International Biodeterioration and Biodegradation, 64, 184-190. http://dx.doi.org/10.1016/j.ibiod.2010.01.002

[14] Arias, M.E., González-Pérez, J.A., González-Vila, F.J. and Ball, A.S. (2005) Soil Health—A New Challenge for Microbiologists and Chemists. International Microbiology, 8, 13-21.

[15] Winding, A., Hund-Rinke, K. and Rutgers, M. (2005) The Use of Microorganisms in Ecological Soil Classification and Assessment Concepts. Ecotoxicology and Environmental Safety, 62, 230-248. http://dx.doi.org/10.1016/j.ecoenv.2005.03.026

[16] Aoshima, H., Kimura, A., Shibutani, A., Okada, C., Matsumiya, Y. and Kubo, M. (2006) Evaluation of Soil Bacterial Biomass Using Environmental DNA Extracted by Slow-Stirring Method. Applied Microbiology and Biotechnology, 71, 875-880. http://dx.doi.org/10.1007/s00253-005-0245-X

[17] Oliverira, A. and Pampulha, M.E. (2006) Effects of Long-Term Heavy Metal Contamination on Soil Microbial Characteristics. Journal of Bioscience and Bioengineering, 102, 157-161. http://dx.doi.org/10.1263/jbb.102.157

[18] Kaplan, C.W. and Kitts, C.L. (2004) Bacterial Succession in a Petroleum Land Treatment Unit. Applied Environmental Microbiology, 70, 1777-1786. http://dx.doi.org/10.1128/AEM.70.3.1777-1786.2004

[19] Li, Z., Xu, J., Tang, C., Wu, J., Muhammad, A. and Wang, H. (2006) Application of 16S rDNA-PCR Amplification and DGGE Fingerprinting for Detection of Shift in Microbial Community Diversity in Cu-, Zn-, and Cd-Contaminated Paddy Soils. Chemosphere, 62, 1374-1380. http://dx.doi.org/10.1016/j.chemosphere.2005.07.050

[20] Matsuno, T., Horii, S., Sato, T., Matsumiya, Y. and Kubo, M. (2013) Analysis of Nitrification in Agricultural Soil and Improvement of Nitrogen Circulation with Autorophic Ammonia-Oxidizing Bacteria. Applied Biochemistry and Biotechonology, 169, 795-809. http://dx.doi.org/10.1007/s12010-012-0029-6

[21] Horii, S., Matsuno, T., Tsuda, H., Sato, T., Matsumiya, Y. and Kubo, M. (2013) Isolation and Identification of PhytateDegrading Bacteria and Their Contribution to Phytate Mineralization in Soil. The Journal of General and Applied Microbiology, 59, 353-360. http://dx.doi.org/10.2323/jgam.59.353

[22] Adhikari, D., Kai, T., Mukai, M., Araki, K.S. and Kubo, M. (2014) A New Proposal for a Soil Fertility Index (SOFIX) for Organic Agriculture and Development of a SOFIX Database for Agricultural Fields. Current Topics in Biotechnology, 8, 81-91.

[23] Seitz, L.M., Mohr, H.E., Burroughs, R. and Sauer, D.B. (1977) Ergosterol as an Indicator of Fungal Invasion in Grains. Cereal Chemistry, 54, 1207-1217.

[24] Muyzer, G. (1993) Profiling of Complex Microbial Populations by Denaturing Gradient Gel Electrophoresis Analysis of Polymerase Chain Reaction-Amplified Genes Coding for 16S rRNA. Applied Environmental Microbiology, 59, 695700.

[25] Matsumiya, Y., Wakita, D., Kimura, A., Sanpa, S. and Kubo, M. (2007) Isolation and Characterization of a LipidDegrading Bacterium and Its Application to Lipid-Containing Wastewater Treatment. Journal of Bioscience and Bioengineering, 103, 325-330. http://dx.doi.org/10.1263/jbb.103.325

[26] Hayase, N., Yano, H., Kudoh, E., Tsutsumi, C., Ushio, K., Miyahara, Y., Tanaka, S. and Nakagawa, K. (2004) Isolation and Characterization of Poly(butylenes succiate co-butylene adipate)-Degrading Microorganism. Journal of Bioscience and Bioengineering, 97, 131-133. http://dx.doi.org/10.1016/S1389-1723(04)70180-2

[27] Sakai, K., Kawano, H., Iwami, A., Nakamura, M. and Moriguchi, M. (2001) Isolation of a Thermophilic Poly-L-Lactide 
Degrading Bacterium from Compost and Its Enzymatic Characterization. Journal of Bioscience and Bioengineering, 92, 298-300. http://dx.doi.org/10.1016/S1389-1723(01)80266-8

[28] De Wolf, E.D. and Isard, S.A. (2007) Disease Cycle Approach to Plant Disease Prediction. Annual Review of Phytopathology, 45, 203-220. http://dx.doi.org/10.1146/annurev.phyto.44.070505.143329 